\title{
Principles of Cutting Process Modelling and New Algorithm Proposal
}

Pavel Zeman, Jaroslav Kovalčík, Martin Vrabec

Department of machining, process planning and metrology, Faculty of mechanical engineering, Czech Technical University in Prague, Czech Republic. E-mail: Pavel.Zeman@fs.cvut.cz, Jaroslav.kovalcik@fs.cvut.cz, Martin.Vrabec@fs.cvut.cz

Nowadays the pressure to increase the efficiency of the machining processes is constantly growing. The efficiency of the machining process can be pursued from two basic perspectives - enhancing the cost-effectiveness of the process (decreasing production costs) or increasing production in time. Via these approaches alone, manufacturers of parts as well as suppliers of machine tools and cutting tools try to improve their position in a highly competitive market. One of the approaches to increase efficiency is the correct choice and subsequent optimal exploitation of the potential of cutting tools and machine tools as well as a reduction in the energy intensity of the cutting processes for a given component. That is what led to the idea of creating an analytical-material model for determining the force interaction between the cutting tool and workpiece, energy intensity and machining process efficiency. The result will be an application that helps technologists in practice to choose correctly the appropriate types of cutting tools, operations, machine tools and also quickly determine the main parameters of the cutting process so that there is the possibility of comparing their results with other variants. The first step and goal is to create an overview of the cutting processes and the associated cutting process modelling, compare their advantages and disadvantages, and then propose an approach of our own.

Keywords: machining, modelling, cutting forces, cutting power, specific cutting force

\section{References}

[1] BRYCHTA, J. (2007). Nové směry v progresivním obrábění. Ostrava: Ediční středisko VŠB - TUO. ISBN 97880-248-1505-3.

[2] ZEMAN, P., MÁDL, J. (2005). The Effect of High Cutting Speed on the Chip Formation Process. 8th CIRP International Workshop on Modeling of Machining Operations, University of Warwick. ISBN 3-937524-24-X.

[3] ZEMAN, P. (2005). The Effect of Cutting Speed on the Chip Formation Process. 17th CFM Conference, Université de Technologie de Troyes, 2005.

[4] ZEMAN, P., MÁDL, J. (2004). Experimental and Simulation Study of Cutting Speed Effect on the Chip Formation Process with a view to the Plastic Flow. MATAR PRAHA 2004 - Proceedings of Sections 2,3,4: Forming machines and forming production systems Industrial robots and automation Machining and forming processes, Společnost pro obráběcí stroje, 2004, ISBN 80-903421-4-0.

[5] ZEMAN, P. (2005). Experimentální a simulační výzkum vlivu řezné rychlosti na proces tvorby tř́sky se zaměřením na plastické deformace obráběcího materiálu. Dissertation. Praha: ČVUT Praha.

[6] ROUD, P. (2013) Metody zefektivněni konstrukce řezných nástrojů. Dissertation. Plzeň: ZČU Plzeň, 81 p.

[7] ZEMAN, P. (2007). Experimentální a simulační výzkum vlivu řezných podmínek na silové jevy při HSC obrábění. ČVUT Praha. 36 p. Research report V-07-001.

[8] Third Wave Systems. Webpage: www.thirdwavesys.com

[9] ALTINTAS, Y. (2000). Manufacturing automation: metal cutting mechanics, machine tools vibrations, and CNC design. New York: Cambridge University Press, 286 s. ISBN 05-216-5973-6.

[10] MUZIKA, Č. (2013). Modelování řezných sil při soustružení.Thesis. Praha: ČVUT, 2013.

[11] DEGNER, W., LUTZE, H., SMEJKAL, E. (2009). Spanende Formung: Theorie - Berechnung - Richtwerte. 16. Aktualisierte Auflage. ISBN 978-3-446-41713-7. Germany.

[12] VÁŇA, J., ZEMAN, P. (2011). Model pro výpočet velikosti silových parametrů řezného procesu. ČVUT Praha. 66 p. Research report V-11-080.

[13] MÁDL, J. (1989). Teorie obrábění. Praha: ČVUT Praha. 156 p.

[14] ZEMAN, P., FOJTU゚, P. (2010). Výzkum řezného procesu. ČVUT Praha. 68s. Research report V-10-083.

[15] VASILKO, K., MÁDL, J. (2012). Teorie obrábění - 1. díl. Univerzita J. E. Purkyně v Ústí nad Labem. 298 p. ISBN 978-80-7414-459-2. 
[16] GROTE, H., ANTONSSON, ERIK K. Springer Handbook of Mechanical engineering. ISBN 978-3-540-491316. $1576 \mathrm{p}$.

[17] TSCHATSCH H. (2009). Applied Machining Technology. Springer. ISBN 978-3-642-01006-4.

[18] Production Technology, 1000 pages, Publisher: McGraw-Hill Education, ISBN-10: 0070964432, ISBN-13: 9780070964433.

[19] KOVALČÍK, J., ZEMAN, P. (2013). Vývoj software pro podporu návrhu technologie obráběnía jejího hodnocení. ČVUT Praha. 107 p. Research report V13-048.

[20] Complete machining solutions: rotating tools. ISCAR. 2008.

[21] Sandvik Coromant. Technická př́ručka. (2010). Available: http://www.sandvik.coromant.com 